
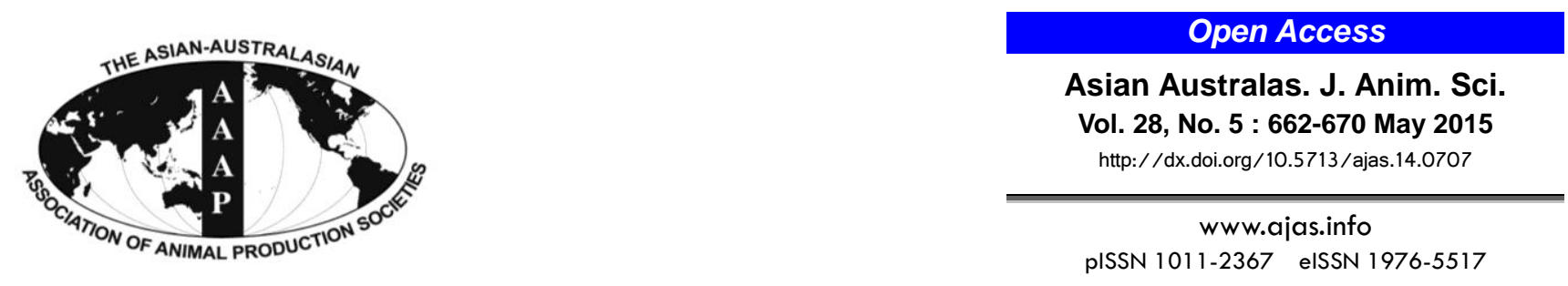

\title{
Effects of Feeding Barley Naturally Contaminated with Fusarium Mycotoxins on Growth Performance, Nutrient Digestibility, and Blood Chemistry of Gilts and Growth Recoveries by Feeding a Non-contaminated Diet
}

\author{
C. Kong, S. Y. Shin, C. S. Park, and B. G. Kim* \\ Department of Animal Science and Technology, Konkuk University, Seoul 143-701, Korea
}

\begin{abstract}
The objectives of this study were to investigate the effects of feeding barley naturally contaminated with Fusarium mycotoxins on growth performance, vulva swelling, and digestibility of dry matter, organic matter, and crude protein of gilts and the recovery of gilts fed normal diets immediately after the exposure to contaminated diets by measuring growth performance and vulva swelling. In Exp. 1, four diets were prepared to contain $0 \%, 15 \%, 30 \%$, or $45 \%$ contaminated barley containing $25.7 \mathrm{mg} / \mathrm{kg}$ deoxynivalenol and $26.0 \mu \mathrm{g} / \mathrm{kg}$ zearalenone. Sixteen gilts with an initial body weight $(\mathrm{BW})$ of $33.3 \mathrm{~kg}$ (standard deviation = 3.0) were individually housed in a metabolism crate and assigned to 4 diets with 4 replicates in a randomized complete block design based on BW. During the 14-d feeding trial, individual BW and feed consumption were measured weekly and the vertical and horizontal lengths of vulva were measured every $3 \mathrm{~d}$. From d 10, feces were collected by the maker-to-marker method for $4 \mathrm{~d}$. Blood samples were collected on $\mathrm{d} 14$. During the overall period, the average daily gain, average daily feed intake, and gain:feed of pigs linearly decreased ( $<<0.01)$ as the dietary concentration of contaminated barley increased. However, the digestibility of crude protein was linearly increased $(p=0.011)$ with the increasing amounts of contaminated barley. Increasing dietary Fusarium mycotoxin concentrations did not influence vulva size, blood characteristic as well as immunoglobulin level of pigs. In the Exp. 2, a corn-soybean meal-based diet was formulated as a recovery diet. Pigs were fed the recovery diet immediately after completion of the Exp. 1. During the 14-d of recovery period, the individual BW and feed consumption were measured weekly and the vertical and horizontal length of vulva were measured every $3 \mathrm{~d}$ from $\mathrm{d} 0$. On $\mathrm{d} 7$, the feed intake of pigs previously fed contaminated diets already reached that of pigs fed a diet with $0 \%$ contaminated barley and no significant difference in growth performance among treatments was observed during d 7 to 14 of the recovery period. In conclusion, increasing levels of mycotoxins in diets linearly decreased the growth performance of pigs, and these damages can be recovered in $7 \mathrm{~d}$ after the diet was replaced with a normal diet. The vulva size, blood characteristic, immune responses were not affected by increasing level of contaminated barley in the diets fed to pigs. (Key Words: Deoxynivalenol, Growth, Mycotoxin, Swine, Zearalenone)
\end{abstract}

\section{INTRODUCTION}

There is growing concern for mycotoxins on swine production as they can cause reduced growth and feed intake, organ damage, and altered immune responses of pigs (Chaytor et al., 2011). Among various mycotoxins, Fusarium mycotoxins are secondary toxic metabolites

\footnotetext{
* Corresponding Author: B. G. Kim. Tel: +82-2-2049-6255, Fax: +82-446-6255, E-mail: bgkim@konkuk.ac.kr Submitted Sept. 11, 2014; Revised Oct. 8, 2014; Accepted Dec. 3, 2014
}

produced by various species of the genus Fusarium such as $F$. graminearum and $F$. culmorum and frequently found in various feedstuffs for swine diet thus have received considerable attention (CAST, 2003; Chaytor et al., 2011). Deoxynivalenol (DON) and zearalenone (ZON) are the most important Fusarium mycotoxins in terms of frequency of occurrence as well as concentration of toxins relative to guidance level (CEC, 2006; Rodrigues and Naehrer, 2012a).

Because pigs are known to be very susceptible to DON (Prelusky et al., 1994), several studies were conducted to find feed additives ameliorating the detrimental effects of 
DON but their effects are still equivocal (Papaioannou et al., 2002; Weaver et al., 2013; Xiao et al., 2013; Kong et al., 2014). The most apparent signs of DON intoxication are reduced feed intake and consequent body weight (BW) loss of pigs. The DON also modulates immune responses as well as affects blood chemistry in pigs (Bergsjo et al., 1993; Swamy et al., 2002; Dänicke et al., 2004b). The ZON known as a mycoestrogen and estrogenic properties of its metabolites have been reported to cause reproductive disorders by hyperestrogenism (Takemura et al., 2007; Kanora and Maes, 2009; Jiang et al., 2010).

Barley ranks in fifth in global grain production (USDA, 2014). Although energy content in barley is about $10 \%$ to $15 \%$ less than that in corn, barley is still a very attractive ingredient for swine diet because of higher contents of crude protein (CP), lysine, and digestible phosphorus compared with corn (NRC, 2012; Woyengo et al., 2014). In addition, feeding diets containing barley up to $60 \%$ at the expense of corn did not show any detrimental effects on animal performances (Kim et al., 2014). A global survey for the incidence of mycotoxins in various feedstuffs indicated that the positive occurrences of DON and ZON in barley were $42 \%$ and $38 \%$, respectively, and the average concentrations of DON and ZON were 1.677 and 0.323 $\mathrm{mg} / \mathrm{kg}$ which are greater than the suggested guidance levels of mycotoxins for swine diets at 0.9 and $0.1 \mathrm{mg} / \mathrm{kg}$, respectively (CEC, 2006; Rodrigues and Naehrer, 2012b). Moreover, it was reported that the effect of Fusarium mycotoxins on growth performance of pigs was dependent on the source of mycotoxin (i.e. purified vs naturally contaminated) in ingredient (Prelusky et al., 1994). However, little data from study feeding contaminated barley with Fusarium mycotoxins to pigs is available. Therefore, the objectives of the present study were to investigate the effects of feeding barley naturally contaminated with Fusarium mycotoxins on growth performance, vulva swelling, and digestibility of dry matter (DM), organic matter (OM), and CP for gilts and the recovery of gilts fed normal diets immediately after the exposure to the contaminated diets by measuring growth performance and vulva size.

\section{MATERIALS AND METHODS}

All the experimental procedures used in the current study were approved by the Institutional Animal Care and Use Committee at Konkuk University.

\section{Exp. 1}

Animals and experimental design: In a 14-d experiment, 16 crossbred gilts with an average initial BW of $33.3 \mathrm{~kg}$ (standard deviation $=3.0$ ) were individually housed in metabolism crates $(0.48 \times 1.49 \mathrm{~m})$ in an environmentally controlled room. The pigs were allotted to 4 dietary treatments in a randomized complete block design with 4 blocks based on BW.

Ingredients, diets, feeding, and sample collection: The concentration of DON in the corn, soybean meal (SBM), control barley, or naturally contaminated barley used were analyzed to be $0.6,1.0,0.3$, or $25.7 \mathrm{mg} / \mathrm{kg}$, respectively, and the concentrations of $\mathrm{ZON}$ were less than the detection limit $(25.0 \mu \mathrm{g} / \mathrm{kg})$ except for contaminated barley which was analyzed to be $26.0 \mu \mathrm{g} / \mathrm{kg}$ (Table 1).

A corn-SBM based diet containing $45 \%$ of control barley was prepared and 3 additional diets were also formulated to contain $15 \%, 30 \%$, or $45 \%$ of the contaminated barley at the expense of the control barley (Table 2). Individual BW and feed consumption were measured on $\mathrm{d} 0,7$, and 14 and at the completion of experiment on d 14 average daily gain (ADG), average daily feed intake (ADFI), and gain:feed (G:F) were calculated. Individual vertical and horizontal lengths of vulva were measured on $\mathrm{d} 0,3,6,9$, and 12. From d 10 to 14, fecal samples were collected quantitatively by the marker-to-marker method as described by Kong and Adeola (2014). Blood samples were collected from all the pigs at the completion of study on $\mathrm{d} 14$.

Mycotoxins and chemical analyses: The concentration of DON and $\mathrm{ZON}$ in the ingredients and diets were determined by using enzyme-linked immunosorbent assay kits (AgraQuant, Romer Labs Inc., Singapore, Republic of Singapore) which had quantification ranges for analysis on DON and ZON from 250 to 5,000 and 25 to $1,000 \mathrm{ng} / \mathrm{mL}$, respectively.

All the fecal samples and orts collected for each gilt were dried in a forced-air oven at $55^{\circ} \mathrm{C}$ to constant weight and ground using a coffee grinder. Dry matter analysis of samples was performed by drying the samples in a forcedair oven at $135^{\circ} \mathrm{C}$ for $2 \mathrm{~h}$ (method 930.15; AOAC, 2005). Nitrogen content of samples was determined by the Kjeldahl method (method 984.13; AOAC, 2005) using a Buchi K-424 digestion and B-324 distillation apparatus (Buchi, Flawil, Switzerland) and gross energy was determined by adiabatic bomb calorimeter (Parr 1261 bomb calorimeter; Parr Instruments Co., Moline, IL, USA) using benzoic acid as a calibration standard. Serum concentration

Table 1. Mycotoxin concentrations of ground corn, soybean meal, and barley as a control and a naturally contaminated one with Fusarium mycotoxins (as-fed basis), Exp. 1

\begin{tabular}{lcccc}
\hline \multirow{2}{*}{ Mycotoxin } & Ground & Soybean & \multicolumn{2}{c}{ Barley } \\
\cline { 4 - 5 } & corn & meal & Control & Contaminated \\
\hline $\begin{array}{c}\text { Deoxynivalenol } \\
(\mathrm{mg} / \mathrm{kg})\end{array}$ & 0.6 & 1.0 & 0.3 & 25.7 \\
$\begin{array}{l}\text { Zearalenone } \\
(\mu \mathrm{g} / \mathrm{kg})\end{array}$ & $\mathrm{ND}$ & $\mathrm{ND}$ & $\mathrm{ND}$ & 26.0 \\
\hline
\end{tabular}

ND, not detected. 
Table 2. Ingredient and nutrient composition (\%) of experimental diets containing increasing levels of barley contaminated with Fusarium mycotoxins (as-fed basis), Exp. 1

\begin{tabular}{|c|c|c|c|c|}
\hline \multirow{3}{*}{ Item } & \multicolumn{4}{|c|}{$\operatorname{Diet}^{1}$} \\
\hline & \multicolumn{4}{|c|}{ Contaminated barley (\%) } \\
\hline & 0 & 15 & 30 & 45 \\
\hline \multicolumn{5}{|l|}{ Ingredient } \\
\hline Ground corn & 21.8 & 21.8 & 21.8 & 21.8 \\
\hline Soybean meal (48\% CP) & 30.6 & 30.6 & 30.6 & 30.6 \\
\hline Control barley & 45.0 & 30.0 & 15.0 & - \\
\hline Contaminated barley & - & 15.0 & 30.0 & 45.0 \\
\hline Limestone & 0.95 & 0.95 & 0.95 & 0.95 \\
\hline Dicalcium phosphate & 0.75 & 0.75 & 0.75 & 0.75 \\
\hline Salt & 0.40 & 0.40 & 0.40 & 0.40 \\
\hline Vitamin-mineral premix ${ }^{2}$ & 0.50 & 0.50 & 0.50 & 0.50 \\
\hline \multicolumn{5}{|l|}{ Analyzed nutrient and energy } \\
\hline Dry matter & 89.3 & 89.1 & 89.5 & 89.4 \\
\hline Organic matter & 84.2 & 83.5 & 83.0 & 83.3 \\
\hline $\mathrm{CP}$ & 21.6 & 22.1 & 22.8 & 23.8 \\
\hline $\begin{array}{l}\text { Metabolizable energy }{ }^{3} \\
(\mathrm{kcal} / \mathrm{kg})\end{array}$ & 3,131 & 3,131 & 3,131 & 3,131 \\
\hline \multicolumn{5}{|l|}{ Analyzed mycotoxin } \\
\hline Deoxynivalenol (mg/kg) & 0.6 & 6.1 & 7.7 & 14.6 \\
\hline Zearalenone $(\mu \mathrm{g} / \mathrm{kg})$ & ND & 35.4 & 47.8 & 33.7 \\
\hline
\end{tabular}

$\mathrm{CP}$, crude protein; $\mathrm{ND}$, not detected.

${ }^{1}$ Each diet contains $0 \%, 15 \%, 30 \%$, or $45 \%$ contaminated barley at the expense of control barley, respectively.

${ }^{2}$ Provided the following quantities per $\mathrm{kg}$ of complete diet: vitamin A, 25,000 IU; vitamin $\mathrm{D}_{3}, 4,000 \mathrm{IU}$; vitamin E, $50 \mathrm{IU}$; vitamin $\mathrm{K}, 5.0 \mathrm{mg}$; thiamin, $4.9 \mathrm{mg}$; riboflavin, $10.0 \mathrm{mg}$; pyridoxine, $4.9 \mathrm{mg}$; vitamin $\mathrm{B}_{12}$, $0.06 \mathrm{mg}$; pantothenic acid, $37.5 \mathrm{mg}$; folic acid, $1.10 \mathrm{mg}$; niacin, $62 \mathrm{mg}$; biotin, $0.06 \mathrm{mg} ; \mathrm{Cu}, 25 \mathrm{mg}$ as copper sulfate; $\mathrm{Fe}, 268 \mathrm{mg}$ as iron sulfate; I, $5.0 \mathrm{mg}$ as potassium iodate; $\mathrm{Mn}, 125 \mathrm{mg}$ as manganese sulfate; $\mathrm{Se}$, $0.38 \mathrm{mg}$ as sodium selenite; $\mathrm{Zn}, 313 \mathrm{mg}$ as zinc oxide; butylatedhydroxytoluene, $50 \mathrm{mg}$.

${ }^{3}$ Calculated value based on NRC (2012).

of immunoglobulin subsets ( $\operatorname{Ig} \mathrm{A}, \operatorname{IgG}$, and $\operatorname{IgM}$ ) was determined on a Cobas Integra 800 analyzer (Roche, Mannheim, Germany). An automated blood chemistry analyzer (Roche Cobas c702; Roche, Germany) was used to measure the amounts of albumin, globulin, alkaline phosphatase (ALP), Ala transaminase (ALT), Asp transaminase (AST), $\gamma$-glutamyl transferase (GGT), blood urea nitrogen (BUN), calcium, glucose, phosphorus, and total protein in the serum samples.

\section{Exp. 2}

Diets and feeding: A 14-d feeding trial was conducted to evaluate the recovery of pigs that previously consumed diets contaminated with mycotoxin in Exp. 1. Immediately after ending of Exp. 1, the pigs were fed a corn-SBM-based standard diet (Table 3) which met or exceed the nutrient requirement estimates of pigs (NRC, 1998). Individual pig BW and feed consumption were measured on $\mathrm{d} 0,7$, and 14 and the vertical and horizontal lengths of vulva were
Table 3. Ingredient and nutrient composition (\%) of recovery diet (as-fed basis), Exp. 2

\begin{tabular}{lc}
\hline Item & Diet \\
\hline Ingredient & 67.2 \\
$\quad$ Ground corn & 28.0 \\
Soybean meal $(48 \% \mathrm{CP})$ & 2.00 \\
Soybean oil & 0.20 \\
L-Lys $\mathrm{HCl}(78.8 \%)$ & 0.90 \\
Limestone & 1.00 \\
Dicalcium phosphate & 0.40 \\
Salt & 0.10 \\
Vitamin premix ${ }^{1}$ & 0.20 \\
Mineral premix ${ }^{2}$ & \\
Analyzed nutrient and energy & 84.5 \\
Dry matter & 19.1 \\
CP & 3,384 \\
Metabolizable energy & 3 (kcal/kg)
\end{tabular}

$\mathrm{CP}$, crude protein.

${ }^{1}$ Provided the following quantities per kg of diet: vitamin A, 20,000 IU; vitamin $\mathrm{D}_{3}, 4,200 \mathrm{IU}$; vitamin $\mathrm{E}, 100 \mathrm{IU}$; vitamin $\mathrm{K}_{3}, 5.6 \mathrm{mg}$; thiamin, $2.8 \mathrm{mg}$; riboflavin, $5.5 \mathrm{mg}$; pantothenic acid, $14 \mathrm{mg}$; pyridoxin, $4.2 \mathrm{mg}$; biotin, $0.1 \mathrm{mg}$; cyanocobalamin, $0.042 \mathrm{mg}$; niacin, $42 \mathrm{mg}$; folacin, 1.1 $\mathrm{mg}$; ethoxyquin, $1.1 \mathrm{mg}$.

${ }^{2}$ Provided the following quantities as milligram per $\mathrm{kg}$ of diet: $\mathrm{Fe}, 100 \mathrm{mg}$ as iron sulfate; $\mathrm{Cu}, 70 \mathrm{mg}$ as copper sulfate; $\mathrm{Zn}, 48 \mathrm{mg}$ as zinc sulfate; $\mathrm{Mn}, 60 \mathrm{mg}$ as manganese sulfate; $\mathrm{Co}, 0.4 \mathrm{mg}$ as cobalt sulfate; I, $0.8 \mathrm{mg}$ as calcium iodate; $\mathrm{Se}, 0.5 \mathrm{mg}$ as sodium selenite.

${ }^{3}$ Calculated value based on NRC (2012).

measured every 3 days from $\mathrm{d} 0$ to 14 .

\section{Calculations and statistical analyses}

For each of the experimental diets, the apparent total tract digestibility of $\mathrm{DM}, \mathrm{OM}$, and $\mathrm{CP}$ was determined according to the total collection method as described by Kong and Adeola (2014).

The experimental data were statistically analyzed using MIXED procedures of SAS (SAS Inst. Inc., Cary, NC, USA). The independent variables in the model included diet as a fixed effect and block as a random effect. Growth performance including ADG, ADFI, and G:F, immune responses and blood characteristics were response variables and each animal was considered as an experimental unit. Orthogonal polynomial contrasts were used to show linear or quadratic responses to the level of contaminated barley in the experimental diets and specific orthogonal contrasts were also used to compare the recovery results between pigs previously fed diet without and with contaminated barley. The alpha level used for the determination of statistical differences was set at 0.05 . Probability values between 0.05 and 0.10 were considered tendencies.

\section{RESULTS}

Exp. 1

Mycotoxin analysis: The concentrations of DON and 
$\mathrm{ZON}$ in diets containing $0 \%, 15 \%, 30 \%$, or $45 \%$ contaminated barley were analyzed to be $0.6,6.1,7.7$, or $14.6 \mathrm{mg} / \mathrm{kg}$ and $23.8,35.4,47.8$, or $33.7 \mu \mathrm{g} / \mathrm{kg}$, respectively (Table 2).

Growth performance and vulva size: From d 0 to 7 , the ADFI for pigs fed increasing level of the contaminated barley in the diets showed linearly decreasing trend $(\mathrm{p}=$ $0.056)$ and the ADG and G:F decreased linearly $(p=0.011)$ as the contaminated barley levels increased (Table 4). From d 7 to 14, the ADG and ADFI of pigs linearly decreased $(\mathrm{p}<0.01)$ with increasing level of the contaminated barley in the diets whereas the G:F of pigs showed linearly decreasing trend $(p=0.063)$. On $d 14$, the final BW of pigs fed diets with increasing level of the contaminated barley linearly decreased $(\mathrm{p}=0.017)$. During the overall period, all growth performance measurements linearly decreased $(p<0.01)$ as the level of contaminated barley in the diets fed to pigs increased.

The vulva size of pigs fed the diets with increasing level of contaminated barley was not affected throughout the 12-d period (Table 5).

Digestibility: The daily feed DM, OM, and CP intake as well as the respective feces components output linearly decreased $(\mathrm{p}<0.01)$ as the level of the contaminated barley in the diets increased (Table 6). However, the CP digestibility linearly increased $(\mathrm{p}=0.011)$, and the digestibility of DM $(p=0.065)$ and OM $(p=0.060)$ showed increasing trend as the contaminated barley in the diets increased.

Serum immunoglobulin and blood characteristics: The concentrations of serum $\operatorname{Ig} \mathrm{A}$, $\operatorname{IgG}$, and $\operatorname{IgM}$ were not influenced by the increase of the contaminated barley in diets fed to pigs (Table 7). Feeding of increasing level of the contaminated barley to pigs linearly increased BUN ( $p=$ 0.016) whereas other blood chemistry measurements were not affected.

\section{Exp. 2}

Growth performance: From d 0 to 7 , the ADG and G:F of pigs previously fed $15 \%$ or $45 \%$ of the contaminated barley in diets was greater $(\mathrm{p}<0.05)$ compared with pigs previously fed the control barley in diet (Table 8). No difference was observed in the growth performance among the pigs previously fed the diets containing $0 \%, 15 \%, 30 \%$, or $45 \%$ of contaminated barley from d 7 to 14 . For the overall period, the ADG of pigs previously fed $15 \%$ or $45 \%$ of the contaminated barley in diets was greater $(\mathrm{p}<0.05)$ compared with the pigs previously fed the control barley diet.

Vulva size: During the recovery period, the vulva size measured was not influenced by the levels of the contaminated barley in diets fed previously (Table 9).

\section{DISCUSSION}

\section{Exp. 1}

The difference between the analyzed and calculated concentrations of mycotoxins in the experimental diets based on the analyzed values of the individual ingredient was observed in the present study. This is in agreement with

Table 4. Growth performance of pigs fed experimental diets containing increasing amounts of barley naturally contaminated with Fusarium mycotoxins ${ }^{1}$, Exp. 1

\begin{tabular}{|c|c|c|c|c|c|c|c|}
\hline \multirow{3}{*}{ Item } & \multicolumn{4}{|c|}{ Diet $^{2}$} & \multirow{3}{*}{ SEM } & \multirow{2}{*}{\multicolumn{2}{|c|}{$\mathrm{p}$-value }} \\
\hline & \multicolumn{4}{|c|}{ Contaminated barley $(\%)$} & & & \\
\hline & 0 & 15 & 30 & 45 & & Linear & Quadratic \\
\hline \multicolumn{8}{|l|}{ d 0 to 7} \\
\hline Initial BW (kg) & 32.5 & 33.0 & 33.0 & 34.8 & 1.0 & 0.143 & 0.497 \\
\hline $\operatorname{ADG}(\mathrm{g} / \mathrm{d})$ & 589 & 614 & 475 & 57 & 122 & 0.011 & 0.104 \\
\hline ADFI (g/d) & 1,332 & 1,297 & 1,155 & 848 & 163 & 0.056 & 0.425 \\
\hline $\mathrm{G}: \mathrm{F}$ & 0.42 & 0.47 & 0.38 & 0.06 & 0.08 & 0.011 & 0.044 \\
\hline Final BW (kg) & 36.7 & 37.3 & 36.3 & 35.2 & 1.3 & 0.385 & 0.517 \\
\hline \multicolumn{8}{|l|}{ d 7 to 14} \\
\hline $\operatorname{ADG}(\mathrm{g} / \mathrm{d})$ & 575 & 511 & 211 & 171 & 81 & 0.002 & 0.881 \\
\hline ADFI (g/d) & 1,768 & 1,658 & 1,281 & 1,071 & 86 & $<0.001$ & 0.572 \\
\hline $\mathrm{G}: \mathrm{F}$ & 0.32 & 0.31 & 0.13 & 0.16 & 0.07 & 0.063 & 0.724 \\
\hline Final BW (kg) & 40.7 & 40.9 & 37.8 & 36.4 & 1.2 & 0.017 & 0.531 \\
\hline \multicolumn{8}{|l|}{ d 0 to 14} \\
\hline $\mathrm{ADG}(\mathrm{g} / \mathrm{d})$ & 582 & 563 & 343 & 114 & 69 & $<0.001$ & 0.163 \\
\hline ADFI (g/d) & 1,550 & 1,478 & 1,218 & 959 & 114 & 0.003 & 0.435 \\
\hline $\mathrm{G}: \mathrm{F}$ & 0.37 & 0.38 & 0.26 & 0.11 & 0.04 & $<0.001$ & 0.087 \\
\hline
\end{tabular}

SEM, standard error of the mean; BW, body weight; ADG, average daily gain; ADFI, average daily feed intake; G:F, gain:feed.

${ }^{1}$ Each least squares mean represents 4 observations.

${ }^{2}$ Each diet contains $0 \%, 15 \%, 30 \%$, or $45 \%$ contaminated barley at the expense of control barley, respectively. 
Table 5. Vulva size of pigs fed experimental diets containing increasing amounts of barley naturally contaminated with Fusarium mycotoxins ${ }^{1}$, Exp. 1

\begin{tabular}{|c|c|c|c|c|c|c|c|}
\hline \multirow{3}{*}{ Item } & \multicolumn{4}{|c|}{ Diet $^{2}$} & \multirow{3}{*}{ SEM } & \multirow{2}{*}{\multicolumn{2}{|c|}{ p-value }} \\
\hline & \multicolumn{4}{|c|}{ Contaminated barley (\%) } & & & \\
\hline & 0 & 15 & 30 & 45 & & Linear & Quadratic \\
\hline \multicolumn{8}{|l|}{$\mathrm{d} 0$} \\
\hline Width (mm) & 19.7 & 17.3 & 19.0 & 16.5 & 2.3 & 0.432 & 0.990 \\
\hline Length (mm) & 24.7 & 22.0 & 19.0 & 21.5 & 1.8 & 0.121 & 0.135 \\
\hline $\operatorname{Area}^{3}\left(\mathrm{~mm}^{2}\right)$ & 245 & 193 & 182 & 179 & 36 & 0.198 & 0.466 \\
\hline \multicolumn{8}{|l|}{ d 3} \\
\hline Width (mm) & 20.0 & 16.3 & 19.8 & 17.5 & 1.9 & 0.653 & 0.706 \\
\hline Length (mm) & 27.0 & 26.3 & 23.3 & 26.8 & 1.5 & 0.601 & 0.203 \\
\hline Area $\left(\mathrm{mm}^{2}\right)$ & 284 & 215 & 233 & 235 & 36 & 0.439 & 0.350 \\
\hline \multicolumn{8}{|l|}{ d 6} \\
\hline Width (mm) & 20.0 & 17.3 & 20.0 & 17.5 & 1.9 & 0.589 & 0.949 \\
\hline Length (mm) & 27.8 & 28.5 & 26.8 & 27.0 & 1.4 & 0.531 & 0.860 \\
\hline Area $\left(\mathrm{mm}^{2}\right)$ & 287 & 247 & 269 & 236 & 35 & 0.421 & 0.922 \\
\hline \multicolumn{8}{|l|}{ d 9} \\
\hline Width (mm) & 21.5 & 18.3 & 20.8 & 18.0 & 2.0 & 0.397 & 0.904 \\
\hline Length (mm) & 31.0 & 27.5 & 25.8 & 27.5 & 1.9 & 0.176 & 0.193 \\
\hline Area $\left(\mathrm{mm}^{2}\right)$ & 344 & 251 & 269 & 248 & 43 & 0.191 & 0.425 \\
\hline \multicolumn{8}{|l|}{ d 12} \\
\hline Width (mm) & 20.5 & 16.5 & 19.3 & 18.0 & 1.7 & 0.551 & 0.443 \\
\hline Length (mm) & 30.3 & 27.8 & 26.5 & 27.8 & 1.5 & 0.229 & 0.247 \\
\hline Area $\left(\mathrm{mm}^{2}\right)$ & 319 & 228 & 260 & 250 & 37 & 0.314 & 0.308 \\
\hline
\end{tabular}

SEM, standard error of the mean.

${ }^{1}$ Each least squares mean represents 4 observations except the diet containing $0 \%$ contaminated barley in d 0 ( 3 observations).

${ }^{2}$ Each diet contains $0,15,30$, and $45 \%$ contaminated barley at the expense of control barley, respectively.

${ }^{3}$ Area $\left(\mathrm{mm}^{2}\right)=[$ Width $(\mathrm{mm}) \times$ Length $(\mathrm{mm})] / 2$.

Swamy et al. (2003) who also observed much higher analyzed values of DON compared with the intended values in diets. This might be attributed to uneven distribution of mycotoxins in the ingredients used. The analyzed mycotoxin also showed that the contaminated barley used in the present study was primarily contaminated with DON rather than $\mathrm{ZON}$.
Increasing level of contaminated barley with Fusarium mycotoxins negatively affected growth performance of growing pigs. Feed intake depression and consequent decrease of BW gain were commonly observed and are considered as the major adverse effects of feeding DONcontaminated diets to pigs (Swamy et al., 2003; Goyarts et al., 2005; Mok et al., 2013) and these effects were also

Table 6. Dry matter $(\mathrm{DM})$, organic matter $(\mathrm{OM})$, and crude protein $(\mathrm{CP})$ digestibility of pigs fed experimental diets containing increasing amounts of barley naturally contaminated with Fusarium mycotoxins ${ }^{1}$, Exp. 1

\begin{tabular}{|c|c|c|c|c|c|c|c|}
\hline \multirow{3}{*}{ Item } & \multicolumn{4}{|c|}{ Diet $^{2}$} & \multirow{3}{*}{ SEM } & \multirow{2}{*}{\multicolumn{2}{|c|}{ p-value }} \\
\hline & \multicolumn{4}{|c|}{ Contaminated barley (\%) } & & & \\
\hline & 0 & 15 & 30 & 45 & & Linear & Quadratic \\
\hline DM intake $(\mathrm{kg} / \mathrm{d})$ & 1.66 & 1.57 & 1.17 & 1.03 & 0.09 & 0.001 & 0.820 \\
\hline OM intake $(\mathrm{kg} / \mathrm{d})$ & 1.57 & 1.47 & 1.08 & 0.96 & 0.08 & $<0.001$ & 0.882 \\
\hline $\mathrm{CP}$ intake $(\mathrm{g} / \mathrm{d})$ & 404 & 388 & 297 & 274 & 22 & 0.002 & 0.881 \\
\hline Fecal DM output (g/d) & 322 & 294 & 205 & 168 & 29 & 0.004 & 0.890 \\
\hline Fecal OM output (g/d) & 281 & 255 & 174 & 142 & 26 & 0.004 & 0.908 \\
\hline Fecal CP output (g/d) & 82.1 & 72.5 & 49.9 & 34.4 & 9.1 & 0.005 & 0.757 \\
\hline DM digestibility (\%) & 80.4 & 81.3 & 83.0 & 83.8 & 1.2 & 0.065 & 0.954 \\
\hline OM digestibility (\%) & 81.8 & 82.7 & 84.5 & 85.3 & 1.2 & 0.060 & 0.969 \\
\hline $\mathrm{CP}$ digestibility (\%) & 79.3 & 81.4 & 84.4 & 87.6 & 1.8 & 0.011 & 0.756 \\
\hline
\end{tabular}

SEM, standard error of the mean.

${ }^{1}$ Each least squares mean represents 4 observations except the diet containing $0 \%$ contaminated barley ( 3 observations).

${ }^{2}$ Each diet contains $0 \%, 15 \%, 30 \%$, or $45 \%$ contaminated barley at the expense of control barley, respectively. 
Table 7. Immunoglobulin and biological blood assay of pigs fed experimental diets containing increasing amounts of barley naturally contaminated with Fusarium mycotoxins ${ }^{1,2}$, Exp. 1

\begin{tabular}{|c|c|c|c|c|c|c|c|}
\hline \multirow{3}{*}{ Item } & \multicolumn{4}{|c|}{ Diet $^{3}$} & \multirow{3}{*}{ SEM } & \multirow{2}{*}{\multicolumn{2}{|c|}{$\mathrm{p}$-value }} \\
\hline & \multicolumn{4}{|c|}{ Contaminated barley (\%) } & & & \\
\hline & 0 & 15 & 30 & 45 & & Linear & Quadratic \\
\hline \multicolumn{8}{|l|}{ Immunoglobulin (mg/dL) } \\
\hline $\operatorname{Ig} \mathrm{A}$ & 46.0 & 46.5 & 44.8 & 43.3 & 2.6 & 0.412 & 0.709 \\
\hline $\operatorname{IgG}$ & 661 & 662 & 662 & 745 & 46 & 0.254 & 0.399 \\
\hline $\operatorname{IgM}$ & 46.3 & 72.5 & 60.3 & 85.3 & 11.6 & 0.075 & 0.958 \\
\hline \multicolumn{8}{|l|}{ Biological blood assay ${ }^{5}$} \\
\hline Albumin $(\mathrm{g} / \mathrm{dL})$ & 3.98 & 4.00 & 3.43 & 3.68 & 0.22 & 0.161 & 0.615 \\
\hline Globulin (g/dL) & 2.50 & 2.68 & 3.33 & 3.20 & 0.29 & 0.062 & 0.616 \\
\hline Albumin:globulin & 1.82 & 1.50 & 1.10 & 1.17 & 0.28 & 0.090 & 0.493 \\
\hline Total protein $(\mathrm{g} / \mathrm{dL})$ & 6.48 & 6.68 & 6.75 & 6.88 & 0.26 & 0.296 & 0.887 \\
\hline ALP (U/L) & 206 & 117 & 102 & 99 & 40 & 0.094 & 0.304 \\
\hline ALT (U/L) & 38.3 & 44.3 & 43.5 & 52.0 & 4.3 & 0.064 & 0.777 \\
\hline AST (U/L) & 90.0 & 67.8 & 39.5 & 79.3 & 31.9 & 0.682 & 0.357 \\
\hline GGT, U/L & 65.8 & 55.8 & 54.5 & 43.5 & 11.8 & 0.231 & 0.967 \\
\hline BUN (mg/dL) & 15.9 & 19.3 & 17.4 & 21.6 & 1.2 & 0.016 & 0.737 \\
\hline Calcium (mg/dL) & 10.7 & 11.2 & 10.4 & 10.6 & 0.3 & 0.449 & 0.755 \\
\hline Glucose (mg/dL) & 81.8 & 69.8 & 81.3 & 74.3 & 3.6 & 0.516 & 0.509 \\
\hline Phosphorus (mg/dL) & 10.1 & 11.1 & 9.2 & 9.6 & 0.4 & 0.136 & 0.463 \\
\hline
\end{tabular}

SEM, standard error of the mean; ALP, alkaline phosphatase; ALT, Ala transaminase; AST, Asp transaminase; BUN, blood urea nitrogen; GGT, $\gamma$-glutamyl transferase.

${ }^{1}$ Each least squares mean represents 4 observations.

${ }^{2}$ Blood samples were collected at the end of the 14-d trial.

${ }^{3}$ Each diet contains $0 \%, 15 \%, 30 \%$, or $45 \%$ contaminated barley at the expense of control barley, respectively.

observed in the present study. Moreover, the reductions in value (93.8\%) predicted by the equation derived from ADG of pigs fed diet containing $45 \%$ contaminated barley literature data on growth performance of pigs exposed to compared with diet containing 0\% contaminated barley various levels of DON (Mok et al., 2013). Considering the from d 0 to 7,7 to 14 , and the overall period, were $90.3 \%$, guidance levels of DON and ZON for swine diets at 0.9 and $70.3 \%$, and $80.4 \%$, respectively, which were close to the $0.1 \mathrm{mg} / \mathrm{kg}$, respectively (CEC, 2006), the concentrations of

Table 8. Growth performance of pigs fed the recovery $\operatorname{diet}^{1}$, Exp. 2

\begin{tabular}{|c|c|c|c|c|c|c|c|c|c|}
\hline \multirow{3}{*}{ Item } & \multicolumn{4}{|c|}{ Diet $^{2}$} & \multirow{3}{*}{ SEM } & \multirow{3}{*}{$\mathrm{p}$-value } & \multirow{2}{*}{\multicolumn{3}{|c|}{$\mathrm{p}$-values for contrast $(\%)$}} \\
\hline & \multicolumn{4}{|c|}{ Contaminated barley (\%) } & & & & & \\
\hline & 0 & 15 & 30 & 45 & & & 0 vs 15 & 0 vs 30 & 0 vs 45 \\
\hline \multicolumn{10}{|l|}{ d 0 to 7} \\
\hline Initial BW (kg) & 46.8 & 46.3 & 42.8 & 41.6 & 1.5 & 0.085 & 0.826 & 0.085 & 0.035 \\
\hline $\mathrm{ADG}(\mathrm{g} / \mathrm{d})$ & 614 & 1,032 & 589 & 1,086 & 86 & 0.004 & 0.008 & 0.842 & 0.004 \\
\hline ADFI (g/d) & 1,976 & 2,281 & 1,804 & 2,110 & 117 & 0.090 & 0.099 & 0.329 & 0.441 \\
\hline G:F & 0.31 & 0.44 & 0.33 & 0.51 & 0.03 & 0.005 & 0.017 & 0.644 & 0.002 \\
\hline Final BW (kg) & 51.1 & 53.6 & 46.9 & 49.2 & 1.8 & 0.136 & 0.369 & 0.137 & 0.482 \\
\hline \multicolumn{10}{|l|}{ d 7 to 14} \\
\hline $\operatorname{ADG}(\mathrm{g} / \mathrm{d})$ & 1,289 & 1,389 & 1,236 & 1,461 & 86 & 0.313 & 0.432 & 0.670 & 0.192 \\
\hline ADFI (g/d) & 2,594 & 2,474 & 2,184 & 2,781 & 191 & 0.233 & 0.668 & 0.164 & 0.506 \\
\hline $\mathrm{G}: \mathrm{F}$ & 0.50 & 0.60 & 0.56 & 0.53 & 0.06 & 0.629 & 0.233 & 0.467 & 0.728 \\
\hline Final BW (kg) & 60.1 & 63.3 & 55.5 & 59.4 & 2.2 & 0.174 & 0.340 & 0.175 & 0.828 \\
\hline \multicolumn{10}{|l|}{ d 0 to 14} \\
\hline $\mathrm{ADG}(\mathrm{g} / \mathrm{d})$ & 952 & 1211 & 913 & 1273 & 75 & 0.016 & 0.036 & 0.718 & 0.014 \\
\hline ADFI (g/d) & 2,285 & 2,378 & 1,994 & 2,445 & 132 & 0.148 & 0.630 & 0.153 & 0.411 \\
\hline G:F & 0.42 & 0.52 & 0.46 & 0.52 & 0.03 & 0.147 & 0.059 & 0.421 & 0.056 \\
\hline
\end{tabular}

SEM, standard error of the mean; BW, body weight; ADG, average daily gain; ADFI, average daily feed intake; G:F, gain:feed

${ }^{1}$ Each least squares mean represents 4 observations.

${ }^{2}$ Each of previously fed diets contained $0 \%, 15 \%, 30 \%$, or $45 \%$ contaminated barley at the expense of control barley, respectively. 
Table 9. Vulva size of pigs fed the recovery $\operatorname{diet}^{1}$, Exp. 2

\begin{tabular}{|c|c|c|c|c|c|c|c|c|c|}
\hline \multirow{3}{*}{ Item } & \multicolumn{4}{|c|}{ Diet $^{2}$} & \multirow{3}{*}{ SEM } & \multirow{3}{*}{ p-value } & \multirow{2}{*}{\multicolumn{3}{|c|}{$\mathrm{p}$-values for contrast $(\%)$}} \\
\hline & \multicolumn{4}{|c|}{ Contaminated barley (\%) } & & & & & \\
\hline & 0 & 15 & 30 & 45 & & & 0 vs 15 & 0 vs 30 & 0 vs 45 \\
\hline \multicolumn{10}{|l|}{$\overline{\mathrm{d} 0}$} \\
\hline Width (mm) & 19.8 & 16.5 & 20.3 & 16.8 & 2.1 & 0.485 & 0.299 & 0.869 & 0.336 \\
\hline Length (mm) & 29.3 & 28.3 & 27.5 & 26.8 & 1.6 & 0.721 & 0.666 & 0.455 & 0.294 \\
\hline $\operatorname{Area}^{3}\left(\mathrm{~mm}^{2}\right)$ & 610 & 471 & 567 & 448 & 80 & 0.468 & 0.252 & 0.714 & 0.187 \\
\hline \multicolumn{10}{|l|}{ d 3} \\
\hline Width (mm) & 27.0 & 26.8 & 28.5 & 28.0 & 2.0 & 0.914 & 0.932 & 0.610 & 0.733 \\
\hline Length (mm) & 31.0 & 31.0 & 31.3 & 32.8 & 1.0 & 0.538 & 1.000 & 0.858 & 0.228 \\
\hline Area $\left(\mathrm{mm}^{2}\right)$ & 840 & 831 & 892 & 924 & 88 & 0.856 & 0.944 & 0.685 & 0.512 \\
\hline \multicolumn{10}{|l|}{ d 6} \\
\hline Width (mm) & 27.5 & 26.8 & 27.8 & 29.5 & 1.8 & 0.735 & 0.771 & 0.923 & 0.445 \\
\hline Length (mm) & 33.8 & 32.0 & 30.8 & 33.0 & 1.1 & 0.300 & 0.286 & 0.083 & 0.638 \\
\hline Area $\left(\mathrm{mm}^{2}\right)$ & 931 & 857 & 854 & 974 & 77 & 0.639 & 0.515 & 0.496 & 0.698 \\
\hline \multicolumn{10}{|l|}{ d 9} \\
\hline Width (mm) & 27.3 & 28.3 & 29.5 & 29.8 & 1.0 & 0.325 & 0.501 & 0.149 & 0.113 \\
\hline Length (mm) & 33.5 & 31.3 & 31.5 & 33.3 & 0.7 & 0.111 & 0.052 & 0.078 & 0.810 \\
\hline Area $\left(\mathrm{mm}^{2}\right)$ & 915 & 884 & 929 & 989 & 42 & 0.401 & 0.614 & 0.816 & 0.246 \\
\hline \multicolumn{10}{|l|}{ d 12} \\
\hline Width (mm) & 27.3 & 27.0 & 29.5 & 30.5 & 1.1 & 0.139 & 0.877 & 0.187 & 0.069 \\
\hline Length (mm) & 33.0 & 30.5 & 32.0 & 32.3 & 0.8 & 0.218 & 0.050 & 0.390 & 0.515 \\
\hline Area $\left(\mathrm{mm}^{2}\right)$ & 900 & 824 & 947 & 984 & 50 & 0.193 & 0.305 & 0.517 & 0.261 \\
\hline
\end{tabular}

SEM, standard error of the mean.

${ }^{1}$ Each least squares mean represents 4 observations.

${ }^{2}$ Each of previously fed diets contained $0 \%, 15 \%, 30 \%$, or $45 \%$ contaminated barley at the expense of control barley, respectively.

${ }^{3}$ Area $\left(\mathrm{mm}^{2}\right)=[$ Width $(\mathrm{mm}) \times$ Length $(\mathrm{mm})] / 2$.

DON in the contaminated diets were above the guidance level while those of $\mathrm{ZON}$ were not. In addition, the vulva swelling which is one of common clinical symptoms of pigs exposed to ZON was not observed in the present study. Therefore, it might be speculated that the poor growth performance was primarily attributed to the presence of DON rather than ZON in contaminated diets fed to pigs. However, other unanalyzed Fusarium toxins which might interact with DON could not be excluded as a contributor for the poor growth performance. There was a linear decrease in the G:F of pigs fed diets with increasing levels of contaminated barley with Fusarium mycotoxins from d 0 to 7 during the first week as well as the overall period and this is in accordance with Young et al. (1983) and Smith et al. (1997) who also reported a linear reduction in the G:F as dietary DON increased in the diets. On the contrary, other studies observed a significant depression of feed intake and BW gain but no effect (Swamy et al., 2002) or an increase (Rotter et al., 1994; Swamy et al., 2003) in feed efficiency. This conflict of results among experiments may be, in part, attributed to different physiological stage of pigs (age, sex, or BW), source of contaminations (type of grains), and concentration of mycotoxins (Goyarts et al., 2005).

In contrast to the adverse effects of feeding diets contaminated with Fusarium mycotoxins on the growth performance, the positive effect was shown for the digestibility of DM, OM, and CP. This was in agreement with Dänicke et al. (2004a) who also found a DON-related improvement in nutrient digestibility. Several explanations could be possible for this positive effect. Matthäus et al. (2004) found that there were increased activities of protease, amylase, and non-starch polysaccharide-degrading enzymes in the wheat inoculated with Fusarium culmorum compared with the control wheat and were alterations of the cell penetrating properties by fungus. Reduced feed intake due to the presence of mycotoxin might also be attributed to the increase in nutrient utilization because Haydon et al. (1984) observed that the apparent total tract digestibility of DM and energy tended to increase as the feed intake of $25-\mathrm{kg}$ pigs fed sorghum-SBM based diet decreased. However, Dänicke et al. (2004a) and Goyarts et al. (2005) reported that significant increases in nutrient digestibility for pigs fed diets contaminated with DON regardless of the feeding methods (i.e. ad libitum vs restricted) indicating that levels of feed intake did not affect nutrient digestibility.

Blood urea nitrogen is an indication of renal health and a linear increase of BUN was observed but the values were within the reference range of BUN in pigs (8.2 to 25 $\mathrm{mg} / \mathrm{dL}$; Latimer et al., 2003). Signs of liver damage (ALP, ALT, AST, and GGT) were not altered as the concentration 
of mycotoxin in the diets increased. Similarly, no signs of liver damage were detected in previous studies reported (Dänicke et al., 2004a; Accensi et al., 2006) whereas other study reported that there was a dose-response related decrease in blood measurements for the sign of liver damage (Döll et al., 2003). Two major groups of blood total proteins are albumin and globulin, and their alterations are indicatives of liver damage and abnormal immune functions, respectively (Busher, 1990). In some experiments, increases of serum albumin:globulin ratio were observed in pigs fed diets containing Fusarium mycotoxins (Rotter et al., 1994; Swamy et al., 2003). However, there were no changes in albumin:globulin ratio as well as total protein with increasing level of contaminated barley in experimental diets used in the present study. Rotter et al. (1994) suggested that DON and other Fusarium mycotoxins might directly affect globulin synthesis in the liver and compromise the immune response of pigs exposed to Fusarium mycotoxins. This discrepancy in results might be attributed to differences in age of pigs, types of grain as mycotoxin sources, and composition of Fusarium mycotoxins in grains as well as volume of blood sample collected (Dänicke et al., 2004b).

\section{Exp. 2}

A rapid compensation in feed intake and $\mathrm{BW}$ gain of the pigs fed the corn-SBM-based standard diet for 14 days was in accordance with Dänicke et al. (2004b) who observed quick and complete growth compensatory effects. During the first week of the recovery period, feed intake of pigs previously fed contaminated diets already returned to that of pigs fed diet without contamination and this remained similar following 7 days. In addition, the difference in ADG between the pigs previously fed diets including 0 and $15 \%$ or $45 \%$ contaminated barley was significant for the period during d 0 to 7 and the overall period, which resulted in the greater G:F in the pigs previously fed diet containing $15 \%$ or $45 \%$ contaminated barley for the respective periods.

In conclusion, the present study showed that feeding of barley contaminated with Fusarium mycotoxin negatively affects the growth performance of pigs primarily by feed intake depression but these adverse effects were quickly recovered in 7 days after the diets were replaced to the standard corn-SBM diet. The serum immunoglobulin and blood chemical components were not altered by feeding of contaminated barley diets whereas improvement in the digestibility of DM, OM, and $\mathrm{CP}$ was observed and further research is needed to verify underlying mechanisms on this improvement.

\section{ACKNOWLEDGMENTS}

This paper was supported by the KU Research Professor
Program of Konkuk University and Rural Development Administration (Republic of Korea; PJ010932).

\section{REFERENCES}

Accensi, F., P. Pinton, P. Callu, N. Abella-Bourges, J.-F. Guelfi, F. Grosjean, and I. P. Oswald. 2006. Ingestion of low doses of deoxynivalenol does not affect hematological, biochemical, or immune responses of piglets. J. Anim. Sci. 84:1935-1942.

AOAC. 2005. Official Methods of Analysis, 18th edn. Association of Official Analytical Chemists, Arlington, VA, USA.

Bergsjo, B., W. Langseth, I. Nafstad, J. H. Jansen, and H. J. S. Larsen. 1993. The effects of naturally deoxynivalenolcontaminated oats on the clinical condition, blood parameters, performance and carcass composition of growing pigs. Vet. Res. Commun. 17:283-294.

Busher, J. T. 1990. Serum albumin and globulin. In: Clinical Methods: The History, Physical, and Laboratory Examinations. (Eds. H. Walker, W. Hall, and J. Hurst). Butterworths, Boston, MA, USA.

CAST (Council for Agricultural Science and Technology). 2003. Mycotoxins: risks in plant animal and human systems. Council for Agric. Sci. Technol. Task Force Report No 139, Ames, IA, USA. pp. 58-63.

CEC (Commission of the European Communities). 2006. Commission recommendation of 17 August 2006 on the presence of deoxynivalenol, zearalenone, ochratoxin A, T-2 and HT-2 and fumonisins in products intended for animal feeding. Off. J. Eur. Union L229, 7-9.

Chaytor, A. C., J. A. Hansen, E. van Heugten, M. T. See, and S. W. Kim. 2011. Occurrence and decontamination of mycotoxins in swine feed. Asian Australas. J. Anim. Sci. 24:723-738.

Dänicke, S., H. Valenta, S. Döll, M. Ganter, and G. Flachowsky. 2004a. On the effectiveness of a detoxifying agent in preventing fusario-toxicosis in fattening pigs. Anim. Feed Sci. Technol. 114:141-157.

Dänicke, S., H. Valenta, F. Klobasa, S. Döll, M. Ganter, and G. Flachowsky. 2004b. Effects of graded levels of Fusarium toxin contaminated wheat in diets for fattening pigs on growth performance, nutrient digestibility, deoxynivalenol balance and clinical serum characteristics. Arch. Anim. Nutr. 58:1-17.

Döll, S., S. Dänicke, K. H. Ueberschär, H. Valenta, U. Schnurrbusch, M. Ganter, F. Klobasa, and G. Flachowsky. 2003. Effects of graded levels of Fusarium toxin contaminated maize in diets for female weaned piglets. Arch. Anim. Nutr. 57:311-334.

Drochner, W., M. Schollenberger, H. P. Piepho, S. Götz, U. Lauber, M. Tafaj, F. Klobasa, U. Weiler, R. Claus, and M. Steffl. 2004. Serum IgA-promoting effects induced by feed loads containing isolated deoxynivalenol (DON) in growing piglets. J. Toxicol. Environ. Health A 67:1051-1067.

Goyarts, T., S. Dänicke, H. J. Rothkötter, J. Spilke, U. Tiemann, and M. Schollenberger. 2005. On the effects of a chronic deoxynivalenol intoxication on performance, haematological and serum parameters of pigs when diets are offered either for ad libitum consumption or fed restrictively. J. Vet. Med. A Physiol. Pathol. Clin. Med. 52:305-314.

Haydon, K. D., D. A. Knabe, and T. D. Tanksley, Jr. 1984. Effects of level of feed intake on nitrogen, amino acid and energy 
digestibilities measured at the end of the small intestine and over the total digestive tract of growing pigs. J. Anim. Sci. 59:717-724.

Jiang, S. Z., Z. B. Yang, W. R. Yang, B. Q. Yao, H. Zhao, F. X. Liu, C. C. Chen, and F. Chi. 2010. Effects of feeding purified zearalenone contaminated diets with or without clay enterosorbent on growth, nutrient availability, and genital organs in post-weaning female pigs. Asian Australas. J. Anim. Sci. 23:74-81.

Kanora, A. and D. Maes. 2009. The role of mycotoxins in pig reproduction: A review. Vet. Med. 54:565-576.

Kim, B. G., D. M. Wulf, R. J. Maddock, D. N. Peters, C. Pedersen, Y. Liu, and H. H. Stein. 2014. Effects of dietary barley on growth performance, carcass traits and pork quality of finishing pigs. Rev. Colomb. Cienc. Pecu. 27:102-113.

Kong, C. and O. Adeola. 2014. Invited review: Evaluation of amino acid and energy utilization in feedstuff for swine and poultry diets. Asian Australas. J. Anim. Sci. 27:917-925.

Kong, C., S. Y. Shin, and B. G. Kim. 2014. Evaluation of mycotoxin sequestering agents for aflatoxin and deoxynivalenol: an in vitro approach. SpringerPlus 3:346.

Latimer, K. S., E. A. Mahaffey, and K. W. Prasse. 2003. Duncan and Prasse's Veterinary Laboratory Medicine: Clinical Pathology. 4th ed. Iowa State Press, Ames, IA, USA.

Matthäus, K., S. Dänicke, W. Vahjen, O. Simon, J. Wang, H. Valenta, K. Meyer, A. Strumpf, H. Ziesenib, and G. Flachowsky. 2004. Progression of mycotoxin and nutrient concentrations in wheat after inoculation with Fusarium culmorum. Arch. Anim. Nutr. 58:19-35.

Mok, C. H., S. Y. Shin, and B. G. Kim. 2013. Aflatoxin, deoxynivalenol, and zearalenone in swine diets: Predictions on growth performance. Rev. Colomb. Cienc. Pecu. 26:243-254.

NRC. 1998. Nutrient Requirements of Swine. 10th rev. ed. Natl. Acad. Press, Washington, DC, USA.

NRC. 2012. Nutrient Requirements of Swine. 11th rev. ed. Natl. Acad. Press, Washington, DC, USA.

Papaioannou, D. S., S. C. Kyriakis, A. Papasteriadis, N. Roumbies, A. Yannakopoulos, and C. Alexopoulos. 2002. A field study on the effect of in-feed inclusion of a natural zeolite (clinoptilolite) on health status and performance of sows/gilts and their litters. Res. Vet. Sci. 72:51-59.

Prelusky, D. B., R. G. Gerdes, K. L. Underhill, B. A. Rotter, P. Y. Jui, and H. L. Trenholm. 1994. Effects of low-level dietary deoxynivalenol on haematological and clinical parameters of the pig. Nat. Toxins 2:97-104.

Rodrigues, I. and K. Naehrer. 2012a. A three-year survey on the worldwide occurrence of mycotoxins in feedstuffs and feed. Toxins 4:663-675.
Rodrigues, I. and K. Naehrer. 2012b. Prevalence of mycotoxins in feedstuffs and feed surveyed worldwide in 2009 and 2010. Phytopathol. Mediterr. 51:175-192.

Rotter, B. A., B. K. Thompson, M. Lessard, H. L. Trenholm, and H. Tryphonas. 1994. Influence of low-level exposure to Fusarium mycotoxins on selected immunological and hematological parameters in young swine. Toxicol. Sci. 23:117-124.

Smith, T. K., E. G. McMillan, and J. B. Castillo. 1997. Effect of feeding blends of Fusarium mycotoxin-contaminated grains containing deoxynivalenol and fusaric acid on growth and feed consumption of immature swine. J. Anim. Sci. 75:2184-2191.

Swamy, H. V. L. N., T. K. Smith, E. J. MacDonald, H. J. Boermans, and E. J. Squires. 2002. Effects of feeding a blend of grains naturally contaminated with Fusarium mycotoxins on swine performance, brain regional neurochemistry, and serum chemistry and the efficacy of a polymeric glucomannan mycotoxin adsorbent. J. Anim. Sci. 80:3257-3267.

Swamy, H. V. L. N., T. K. Smith, E. J. MacDonald, N. A. Karrow, B. Woodward, and H. J. Boermans. 2003. Effects of feeding a blend of grains naturally contaminated with Fusarium mycotoxins on growth and immunological measurements of starter pigs, and the efficacy of a polymeric glucomannan mycotoxin adsorbent. J. Anim. Sci. 81:2792-2803.

Takemura, H., J. Y. Shim, K. Sayama, A. Tsubura, B. T. Zhu, and K. Shimoi. 2007. Characterization of the estrogenic activities of zearalenone and zeranol in vivo and in vitro. J. Steroid Biochem. Mol. Biol. 103:170-177.

USDA. 2014. U.S. Grain: World Markets and Trade. http://usda01.library.cornell.edu/usda/current/grainmarket/grain-market-03-10-2014.pdf, Accessed July 15, 2014. Washington, DC, USA.

Weaver, A. C., M. T. See, J. A. Hansen, Y. B. Kim, A. L. P. de Souza, T. F. Middleton, and S. W. Kim. 2013. The use of feed additives to reduce the effects of aflatoxin and deoxynivalenol on pig growth, organ health and immune status during chronic exposure. Toxins 5:1261-1281.

Woyengo, T. A., E. Beltranena, and R. T. Zijlstra. 2014. Controlling feed cost by including alternative ingredients into pig diets: A review. J. Anim. Sci. 92:1293-1305.

Xiao, H., M. M. Wu, B. E. Tan, Y. L. Yin, T. J. Li, D. F. Xiao, and L. Li. 2013. Effects of composite antimicrobial peptides in weanling piglets challenged with deoxynivalenol: I. Growth performance, immune function, and antioxidation capacity. J. Anim. Sci. 91:4772-4780.

Young, L. G., L. McGirr, V. E. Valli, J. H. Lumsden, and A. Lun. 1983. Vomitoxin in corn fed to young pigs. J. Anim. Sci. 57:655-664. 